\title{
Dinamika Eksistensi Peradilan Agama di Indonesia
}

\section{The Dynamics of the Existence of Religious Courts in Indonesia Rinrin Warisni Pribadi \\ Sekolah Tinggi Agama Islam (STAI) Syamsul 'Ulum Gunungpuyuh Sukabumi, Jawa Barat, Indonesia warisnip.81@gmail.com}

\begin{abstract}
Abstrak
Keberadaan lembaga peradilan merupakan condition sine quanon bagi umat Islam. Kajian ini bertujuan untuk memberikan pemahaman mengenai eksistensi dan kewenangan Peradilan Agama di Indonesia. Metode penelitian yang digunakan yaitu metode penelitian kepustakaan (library research). Adapun bahan yang menjadi rujukan berbentuk literatur, dengan deskriptif analitis. Berdasarkan kajian, Peradilan Agama telah mencapai kejayaan pada masa Kerajaan Islam, kemudian mengalami keterpurukan akibat akulturasi pada masa penjajahan dan kembali menancapkan eksistensinya setelah kemerdekaan Indonesia. Faktanya sejarah panjang ini telah mengantarkan wajah Peradilan Agama Indonesia menjadi salah satu peradilan yang mampu berkiprah di dunia internasional. Terlebih dengan disahkannya UndangUndang Nomor 7 Tahun 1989 tentang Peradilan Agama. Maka berdasarkan kajian dapat disimpulkan bahwa dinamika eksistensi Peradilan Agama di Indonesia selama kurang lebih 139 tahun mengalami pasang surut.

Kata Kunci: Dinamika, Eksistensi \& Peradilan Agama
\end{abstract}

\begin{abstract}
Abstarct
The existence of the judiciary is a condition sine quanon for Muslims. This research aims to provide an understanding of the existence and authority of the Religious Courts in Indonesia. The research method used library research. The reference materials were in the form of literature with analytical descriptive. Based on the research, the Religious Courts had achieved success on the Islamic Kingdom, then it was slump due to acculturation during the colonial period and re-established its existence after Indonesian independence. In fact, this long history has brought the Indonesian Religious Courts to become one of the courts capable of taking part in the international community. Especially with the enactment of Law Number 7 of 1989 concerning Religious Courts. So based on the research it can be concluded that the dynamics of the existence of the Religious Courts in Indonesia for approximately 139 years have ebb and flow.
\end{abstract}

Keywords: Dynamics, Existence \& Religious Courts 


\section{PENDAHULUAN}

Keberadaan lembaga peradilan merupakan condition sine quanon bagi umat Islam, yakni sesuatu yang mutlak adanya bagi umat Islam. Di manapun ada Islam dan pemeluknya, maka dapat dipastikan bahwa di tempat tersebut ada lembaga peradilan (Jaenal, 2013).

Masuknya agama Islam ke Indonesia pada abad ke-7 Masehi, dan kini menjadi salah satu negara yang mayoritas beragama Islam, maka pelaksanaan ajaran Islam tidak sebatas pelaksanaan masalah ubudiyahnya saja, namun meliputi semua aspek kehidupan seperti masalah munakahat, muamalah dan menyelesaikan perselisihan keluarga. Hal ini dapat kita lihat dengan bermunculannya lembagalembaga Peradilan Agama di hampir seluruh kerajaan Islam yang ada di Nusantara. Sebagaimana menurut Martius (2016) bahwa keberadaan Peradilan Agama yang berdasarkan hukum Islam merupakan cerminan norma-norma bangsa Indonesia yang mayoritas beragama Islam.

Umat Islam pada saat itu lebih memilih dan nyaman menyelesaikan perkaranya di Peradilan Agama. Hal ini tidak terlepas dari peran ulama sebagai hakimnya, sehingga kedudukan peradilan menjadi lebih berwibawa tidak hanya di mata rakyat tapi juga di mata para raja. Fungsi ulama bukan hanya sebagai hakim, tetapi juga berperan sebagai penasehat para Raja di masa itu.

Pada masa Penjajahan Belanda, eksistensi Peradilan Agama mengalami pasang surut sebagai dampak dari akulturasi dalam bidang hukum. Munculnya teori receptie oleh Van Vollenhoven dan Snouck Hurgronje yang menyatakan bahwa hukum Islam dapat diberlakukan sepanjang tidak bertentangan dengan hukum adat (Nashori, 2007). Imbas dari teori receptie dan kebijakan Snouck tersebut telah membatasi kewenangan Peradilan Agama yang hanya berwenang sebatas masalah munakahat (Sukri, 2012).

Peradilan agama di Indonesia akan menapaki usia ke 139 tahun tepatnya pada tanggal 1 Agustus 2021. Dinamika eksistensi satu abad lebih tidak bisa dibilang sebentar, keberadaan Peradilan Agama bukan tanpa proses perjuangan yang rumit. Adanya pembatasan kewenangan hingga dianggap sebelah mata oleh masyarakat, hingga seolah-olah 
keberadaan Peradilan Agama hanya untuk melegalkan perceraian semata.

Dari pemaparan latar belakang tersebut, penulis tertarik untuk mengkaji lebih dalam bagaimana dinamika eksistensi Peradilan Agama di Indonesia hingga saat ini dan penulis tuangkan dengan judul penelitian "Dinamika Eksistensi Peradilan Agama di Indonesia".

\section{METODE PENELITIAN}

Penelitian ini menggunakan metode penelitian kepustakaan (library research). Metode ini dipakai dengan pertimbangan bahwa hampir seluruh bahan yang menjadi rujukan (historiografi) berbentuk literatur, dengan berbentuk deskriptif analitis (Sugono, 2008).

Penulis akan membatasi ruang lingkup kajian mengenai lebih pada perkembangan Peradilan Agama di Indonesia secara historis, kontekstual dan perkembangan kewenangan Peradilan Agama dalam Undang-Undang Nomor 7 tahun 1989 tentang Peradilan Agama

\section{HASIL DAN PEMBAHASAN}

\section{A. Peradilan Agama Masa} Kerajaan Islam

Peradilan syariah Islam dibentuk dan diselenggarakan oleh
Pemerintah Kerajaan sebagai Pengadilan Negara di Kerajaan. Eksistensi Peradilan Agama mempunyai kedudukan yang sempurna dan mendapatkan bentuknya yang positif dalam system ketatanegaraan Kerajaankerajaan Islam. Sistem ketatanegaraan kerajaan membentuk "trilogy sistem ketatanegaraan" meliputi: (Arto, 2012)

1. Raja (Sultan) sebagai Kepala Negara/Kepala Pemerintahan, Panglima Tertinggi Angkatan Perang, yang dilambangkan dengan Keraton atau Istana.

2. Patih sebagai kepala staf dan Perdana Menteri. Bupati dan Patih di daerah adalah Panglima territorial dan kepala stafnya. Dilambangkan dengan alon-alon

3. Penghulu Ageng sebagai Pejabat Agama yang bertugas mengelola pelaksanaan kehidupan beragama di kerajaan, termasuk di dalamnya soal peradilan yang dilambangkan dengan Mesjid Agung atau Mesjid Gedhe.

Peradilan Agama di masa itu dikenal juga dengan peradilan serambi. Hukum Islam menjadi dasar penyelenggaraan peradilan 
Syariah Islam di kesultanan. Kedudukan, kelembagaan dan kompetensi Peradilan Agama sebagai Peradilan Negara sekaligus sebagai Pengadilan Syariah Islam yang seutuhnya dan andal dalam sistem ketetanegaraan kesultanan telah cukup memadai (Arto, 2012), hal ini didasarkan dari beberapa aspek sebagai berikut:

1. Aspek status. Peradilan Syariah Islam baik dengan sebutannya sebagai Pengadilan Sultan maupun Pengadilan Serambi merupakan lembaga resmi Negara yang dibentuk dan diselenggarakan oleh Negara dalam sistem organisasi dan ketatanegaraan yang berkedudukan langsung di tangan Sultan. Sultan bertindak sebagai qadhi atau hakim, atau didelegasikan kepada penghulu yang bertindak atas nama Sultan.

2. Aspek peran. Pengadilan serambi menjalankan peran dan fungsinya sebagai Pengadilan Negara dan sekaligus sebagai Pengadilan Syariah Islam yang andal dan seutuhnya.

3. Asepek Pengakuan. Pengadilan sebagai lembaga kenegaraan baik secara yuridis, praktis, maupun etis dalam kehidupan ketatanegaraan. Pengadilan Syariah Islam telah diakui dan dihormati sebagai salah satu unsur penyelenggara Negara di kerajaan.

\section{B. Peradilan Agama Masa Penjajahan}

Penjajahan di Indonesia membawa pengaruh yang sangat besar terhadap kehidupan bangsa Indosnesia, termasuk di bidang hukum dan peradilan. Pada masa pemerintahan kolonial Belanda, Peradilan Agama mendapat pengakuan secara resmi. Pada tahun 1882 pemerintah kolonial Belanda mengeluarkan Staatsblad No. 152 yang merupkan pengakuan resmi terhadap eksistensi Peradilan Agama dan Hukum Islam di Indonesia (Rosadi, 2015).

Pengadilan Agama pada masa penjajahan kolonial Belanda dapat dilihat kedalam dua bentuk (Lukito,1998) yaitu: Pertama, toleransi pihak Belanda melalui VOC (Vereenigde Oots-Indische Compagnie) yang memberikan ruang yang agak luas bagi perkembangan Hukum Islam, dikenal dengan penerapan teori Receptie in complex yang dipelopori oleh Lodewijk Willem Christian Van Den Berg yang mengajarkan bahwa hukum yang 
berlaku bagi orang Indonesia asli adalah undang-undang agama mereka.

Teori tersebut menjadi dasar dilahirkannya Staatsblad 1882 Nomor 152 yang mengangkat Peradilan Agama menjadi pengadilan. Badan peradilan ini bernama Priesterraden yang kemudian lazim disebut dengan rapat Agama atau Raad Agama (Ernawati, 2020).

Dalam sistem ketatanegaraan Hindia Belanda, Pengadilan Agama secara yuridis formal memiliki kedudukan sebagai Pengadilan Negara. Kedudukan Peradilan agama menjadi Lembaga Negara, menjadi dasar bagi kewajiban pemerintah membentuk Peradilan Agama di setiap daerah yang sudah ada landraad (pengadilan negeri).

Kedua, upaya intervensi Belanda terhadap hukum Islam dengan menghadapkannya pada hukum Adat. Snouck Hurgronje dan Van Vollenhoven menentang teori Receptie in complex, mereka membuat teori baru, yaitu teori receptive yang menyatakan bahwa hukum yang berlaku di Indonesia bukan hukum Islam melainkan Hukum adat, hukum Islam dapat diberlakukan sepanjang tidak bertentangan dengan hukum adat dan sudah diterima (diresepsi).

Pengaruh teori receptie berdampak dengan dikeluarkannya Staatsblad 1937 No. 116. Staatsblad ini mencabut wewenang yang dimiliki Peradilan Agama dalam persoalan waris dan masalah-masalah lain yang berhubungan dengan harta benda, terutama tanah. Kompetensi Peradilan Agama hanya tebatas masalah perkawinan dan perceraian. Lembaga peradilan bukan lagi lembaga peradilan salaykanya, namun hanya sebatas lembaga agama semata.

\section{Peradilan Agama Masa} Kemerdekaan

Berbagai teori yang digulirkan semasa penjajahan berdampak besar terhadap dinamika eksistensi Peradilan agama di Indonesia. Pada masa awal pasca kemerdekaan teori receptie masih mempengaruhi pola piker para sarjana hukum Indonesia, khususnya yang ada di lembaga legislatif maupun lembaga yudikatif (Gunaryo, 2006). Peradilan Agama melalui Penetapan Pemerintah Nomor 5/S.D tanggal 25 Maret 1946 tidak lagi berada di bawah kementrian kehakiman melainkan berpindah di 
bawah kemetrian Agama (Ernawati, 2020). Setelah berpindah menjadi kewenangan kementrian Agama, masih ada pihak-pihak yang berupaya menghapuskan keberadaan Pengadilan Agama melalui Undang-undang No. 19 tahun 1948 dengan dalih peleburan Pengadilan Agama ke Pengadilan Negeri. Namun upaya tersebut tidak pernah berhasil.

Pemerintah Indonesia pada tanggal 17 Desember 1970 mengesahkan Undang-undang Nomor 14 Tahun 1970 tentang Ketentuan-ketentuan Pokok Kekuasaan Kehakiman yang mengokohkan eksistensi Peradilan Agama dalam sistem ketatanegaraan Indonesia secara yuridis. Selain eksistensi Peradilan Agama, kehendak untuk memperluas kewenangan Peradilan Agama terus diupayakan secara berkesinambungan. Perluasan kewenangan Peradilan Agama secara historis yuridis mulai diatur dalam Undang-undang Nomor 1 Tahun 1974 tentang perkawinan, meliputi cerai, penentuan kebasahan anak, perwalian, penetapan asal-usul anak, dan izin menikah ( Hasan, 2010). Hal tersebut membuktikan bahwa kompetensi yuridis pengadilan agama menjadi lebih luas melalui dua cara: Pertama, pengadilan mendapat kewenangan yang lebih luas terhadap masalah perkawinan dan perceraian. Kedua, kewenangan pengadilan agama mencakup wilayah-wilayah penting yang sebelumnya bukan kewenangan Pengadilan Agama. Kewenangan tersebut meliputi pembagian harta perkawinan, pemberian nafkah bagi pasangan suami istri, dan tanggung jawab anak (Halim, 2002).

Momentum penting terhadap perluasan kompetensi dan eksistensi Peradilan Agama di Indonesia dengan diterbitkannya Undang-undang Nomor 7 tahun 1989 tentang Peradilan Agama (Hasan, 2010). Undang-undang Nomor 7 Tahun 1989 disahkan dan diundangkan pada tanggal 29 Desember 1989. Isi Undangundang tersebut terdiri dari tujuh bab meliputi 108 pasal. Ketujuh bab itu adalah ketentuan umum, susunan peradilan, hokum acara, ketentuan-ketentuan lain, ketentuan peralihan, dan ketentuan penutup (Bisri, 2003).

Dengan disahkannya Undang-undang Nomor 7 tahun 1989 oleh Dewan Perwakilan 
Rakyat (DPR) tercapailah hal-hal sebagai berikut (Djalil, 2006):

1. Terlaksananya ketentuanketentuan yang termaktub dalam Undang-undang Nomor 14 Tahun 1970 tentang Ketentuanketentuan Pokok Kekuasaan Kehakiman;

2. Terlaksanya pembaharuan hukum dalam makna peningkatan dan penyempurnaan pembangunan hukum nasional di bidang Peradilan Agama;

3. Eksistensi Pengadilan agama benar-benar sederajat dan sejajar dengan pengadilan lainnya;

4. Peradilan Agama memiliki kompetensi yang sama di seluruh Indonesia kecuali Peradilan Islam Aceh;
5. Terciptanya unifikasi hukum acara Peradilan Agama

Perkembangan Peradilan Agama dalam Undang-undang Nomor 7 Tahun 1989 mengalami kemajuan-kemajuan yang luar biasa pada hakikatnya merupakan reposisi kedudukan Peradilan Agama sebagai Pengadilan Negara. IV. KESIMPULAN

Peradilan Agama yang berawal dari serambi masjid di masa kejayaan kerajaan Islam memiliki kedudukan dan posisi secara kelembagaan yang kuat. Berdasarkan kajian dapat disimpulkan bahwa dinamika eksistensi Peradilan Agama di Indonesia selama kurang lebih 139 tahun mengalami pasang surut.

\section{DAFTAR PUSTAKA}

Arto, Mukti. (2012). Peradilan Agama dalam Sistem Ketatanegaraan Indonesia: Kajian Historis, Filosofis, Ideologis, Politis, Yuridis, Futuristis dan Pragmatis. Yogyakarta: Pustaka Pelajar.

Bisri, Cik Hasan. (2003). Peradilan Agama di Indonesia. Jakarta: PT Raja Grafindo

Djalil, A. Basiq. (2006). Peradilan Agama di Indonesia. Jakarta: Kencana. Ernawati. (2020). Hukum Acara Peradilan Agama. Depok: Raja Grafindo. Halim, Abdul. (2002). Peradilan Agama Dalam Politik Hukum di Indonesia. Jakarta: PT Raja Grafindo. 
Hasan, Hasbi. (2010). Kompetensi Peradilan Agama dalam Menyelesaikan Perkara Ekonomi Syariah. Depok: Gramata Publishing Anggota IKAPI. Jaenal, Aripin. (2012) Jejak Langkah Peradilan Agama di Indonesia. Jakarta, Kencana Prenada Media Grup.

Martius, A. Havizh. (2016). Peradilan Agama dalam Sistem Hukum Indonesia. Jurnal Hukum Diktum, 14 (1), 55 - 66.

Nashori, Abdul Ghofur. (2007). Peradilan Agama di Indonesia Pasca Undang-undang Nomor 3 Tahun 2006: Sejarah kedudukan dan Kewenangan. Yogyakarta: UII Press.

Rosadi, Aden. (2015). Peradilan Agama di Indonesia (Dinamika Pembentukan Hukum). Bandung: Simbiosa Rekatama Media.

Sukri, Muhammad. (2012). Sejarah Peradilan Agama di Indonesia (Pendekatan Yuridis). Jurnal Ilmiah Al-Syir'ah, 10 (2), 1-8. 